\title{
DESAIN MODEL PEMBELAJARAN TERBUKA DENGAN SISTEM PENDIDIKAN JARAK JAUH (ONLINE) MENURUT BATES DI MASA PENDEMIC COVID-19
}

\author{
Irwin Hidayat ${ }^{1}$, Murtina ${ }^{2}$ Nurul Hasanah $\mathbf{A}^{3}$, Mutiatul Rahma ${ }^{4}$ \\ ${ }^{1}$ Institut Agama Islam Muhammadiyah Sinjai \\ ${ }^{2}$ UPT SMAN 5 Sinjai \\ 3,4 Institut Agama Islam Muhammadiyah Sinjai \\ Email:irwinhid@gmail.com,_murtinamuchtar@gmail.com, nurulhasanaharifuddin@gmail.com, \\ mutiatulrahma1409@gmail.com, Tlp; +6285255400710
}

\begin{abstract}
Abstrak
Literatur ini di buat dengan tujuan untuk untuk menelaah masalah pendidikan di masa pandemi berdasarkan desain model pembelajaran online menurut Bates. Metode penulisan dilakukan dengan pencarian literatur menggunakan kata kunci "pembelajaran terbuka" DAN "pendidikan di masa pandemi" ATAU "model pembelajaran menurut Bates" pada mesin pencarian google cendekia. Didapatkan hasil berupa artikel-artikel ilmiah serta buku baik bereputasi nasional maupun internasional. Hasil penulisan menunjukkan masalah pendidikan Indonesia dimasa pandemi yaitu perubahan metode pembelajaran menjadi model pembelajaran e-learning yang menunjukkan begitu banyak keterbatasan, baik dari sisi pendidik, peserta didik, maupun fasilitas pendukung pembelajaran. Hal ini menuntut terjadinya inovasi pendidikan agar tujuan pembelajaran dapat tercapai secara optimal. Analisis pembelajaran yang sesuai dengan pembelajaran e-learning adalah desain pembelajaran menurut Bates, yang disebut juga sebagai model pembelajaran terbuka. Model pembelajaran terbuka adalah sebuah system pendidikan jarak jauh atau online. Adapun hal yang melatar belakanginya adalah karena ada beberapa hambatan, antara lain lokasi yang tidak geografis, minimnya waktu untuk melakukan pembelajaran seperti pada umumnya, terhambat oleh ekonomi maupun usia. Maka desain pembelajaran seperti ini memberikan alternatif untuk menghilangkan semua hambatan-hambatan untuk tetap belajar. Hal ini juga sesuai dengan model pembelajran e-learning yang merupakan respon dunia pendidikan dalam menyikapi perubahan tersebut.
\end{abstract}

Keyword: Pembelajaran Terbuka, Pendidikan di masa pandemi, e-learning

\section{Latar belakang}

Organisasi kesehatan dunia WHO (World Health Organization) telah menetapkan sindrom pernapasan akut berat yang muncul di kota Wuhan, Tiongkok yaitu Corona Virus 2 (SARS-CoV-2) sebagai pandemi pada 31 Desember 2019. Seluruh dunia terdampak secara global (WHO, 2020). Indonesia saat ini tengah dihadapkan pada masa pandemi, seluruh sektor kehidupan ikut terdampak, termasuk sektor pendidikan. Keterbatasan dari sisi pendidik, peserta didik, orangtua (Asmuni, 2020), serta fasilitas pendukung pendidikan seperti masalah ekomoni. Hal tesebut dapat menjadi masalah yang selalu muncul dan harus dihadapi Indonesia (Salkiah, 2020). Literatur telah menunjukkan berbagai problematika pendidikan di Indonesia pada masa pandemi ini.

Di seluruh belahan dunia kini hampir setiap negara sedang mengalami wabah covid 19 (Hsu et al., 2020; WHO, 2020). Sejak ditetapkan sebagai pandemi oleh WHO (WHO, 2020), berbagai upaya pembuatan kebijakan telah ditetapkan oleh warga dunia sebagai bentuk upaya pemutusan rantai tersebarnya virus Corona, termasuk Indonesia (Hanifah Salsabila et al., 
2020). Di Indonesia sendiri, telah ditetapkan kebijakan pembatasan sosial berskala besar (PSBB) yang berlaku hampir di seluruh wilayah Indonesia (Nasruddin \& Haq, 2020). Aturan ini, menimbulkan berbagai perubahan besar dalam bidang ekonomi, kesehatan, serta pendidikan (Hanifah Salsabila et al., 2020; Nasruddin \& Haq, 2020).

Berdasarkan literatur sebelumnya, berbagai permasalahan muncul terkait pendidikan dimasa pandemi, seperti terdapat permasalahan-permasalahan pada lingkup antara peserta didik maupun orangtua (Asmuni, 2020). Proses pembelajaran daring atau E-Learning sebenarnya sudah ada pada era sebelumnya, hanya saja penerpannya kurang dimaksimalkan, karena keberadaannya belum sama seperti sekarang yaitu mengharuskan untuk menggunakan teknologi untuk menjalankan proses pembelajaran (Ansori \& Sari, 2020). Peran teknologi pada saat sekarang ini sangat memudahkan jalannya proses pembelajaran (Hanifah Salsabila et al., 2020). Maka dari itu kompetensi pendidik sangat dibutuhkan pada era sekarang ini, karena berbagai persoalan-persoalan akan di hadapi pada proses pembelajaran (Sudrajat, 2020). Setiap pendidik harus memiliki keterampilan mengajar karena dengan begitu akan mudah melihat kebutuhan-kebutuhan peserta didik pada saat proses pembelajaran (Sundari \& Muliyawati, 2017). Keterbatasan dari sisi pendidik, peserta didik, serta fasilitas pendukung pendidikan, menjadi masalah yang selalu muncul dan harus dihadapi Indonesia. Literatur telah menunjukkan bahwa problematika pendidikan modern dimasa pandemi ini adalah perubahan paradigma pendidikan ke model pembelajaran jarak jauh atau sering disebut pembelajaran online atau $e$-Learning. Pembelajaran jarak jauh ini, menimbulkan berbagai problematika baik dari sisi pendidik, peserta didik, maupun dari sisi fasilitas pendukung pembelajaran. Dibutuhkan suatu perubahan atau inovasi untuk menyelesaikan permasalah pendidikan tersebut.

\section{Metode}

Metode penulisan dilakukan dengan metode studi pustaka. Pencarian literatur dilakukan dengan menggunakan kata kunci pencarian: "Pembelajaran terbuka" DAN "pendidikan masa pandemi" ATAU "model pembelajaran menurut Bates" pada mesin pencarian google cendekia. Didapatkan hasil berupa artikel-artikel ilmiah serta buku baik bereputasi nasional maupun internasional. Hasil ini kemudian diramu menjadi sebuah tulisan menggunakan aplikasi Misrosoft Word dan aplikasi sitasi Mendeley dengan model penulisan American Psychological Association 7th Edition.

\section{Hasil dan Pembahasan}

\subsection{Desain model pembelajaran terbuka menurut Anthony.W Bates}

Anthony W. Bates merupakan pengembang model pembelajaran berdasarkan filosofis pembelajaran terbuka. Analisis yang sesuai berdasarkan desain pembelajaran menurut Bates atau dapat dikatakan juga sebagai model pembelajaran terbuka dengan menggunkan sebuah system pendidkan jarak jauh atau online. Adapun hal yang melatarbelakanginya adalah karena ada beberapa hambatan, antara lain lokasi yang tidak geografis, minimnya waktu untuk melakukan pembelajaran seperti pada umumnya, terhambat oleh ekonomi maupun usia. Akan tetapi pada model pembelajaran yang dikemukakan oleh Bates ini tetap menekankan adanya interaksi yang fleksibilitas karena kebanyakan pada system pembelajaran jarak jauh, hal tersebut masih sangat kurang atau jarang ditemukan. Desain model pembelajaran jarak jauh ini tidak selamanya hadir secara bersamaan antara pendidik dan peserta didiknya, dengan menggunakan teknologi informasi dalam proses pembelajaran atau biasa di sebut dengan $e$ - 
learning maka akan mempermudah jalannya proses pembelajaran di tengah wabah covid-19 (Pakpahan \& Fitriani, 2020). Maka desain pembelajaran seperti ini memberikan alterntif untuk menghilangkan semua hambatan-hambatan untuk tetap belajar. Hal ini juga sesuai dengan model pembelajran e-learning yang merupakan respon dunia pendidikan dalam menyikapi perubahan tersebut, karena pada saat sekarang ini, pemanfaatan teknolgi sangat dibutuhkan sebagai penunjang dalam proses pembelajaran (Farida \& Yuliana, 2014).

Tujuan utama dari pembelajaran secara tebuka adalah kebijakan kependidikannya. Seperti yang kita ketahui perkembangan teknologi saat ini sangat berpengaruh pada dunia pendidikan (Saragih \& Septamia, 2019). Karakteristik yang paling utama dari pendidikan secara terbuka adalah menghilangkan semua hambatan-hambatan yang ada untuk tetap terus belajar. Dilakukannya hal ini tidak serta merta terdapat persyaratan bagi peseta didik untuk belajar, akan tetapi tidak sedikit ditemukan peserta didik yang memiliki keterbelakangan, jadi menyediakan pendidikan yang sesuai pada karakteristik peserta didik adalah salah satu cara untuk memecahkan atau mengatasi keterbelakangan pada sebagian besar peserta didik. Salah satu tujuan lainnya adalah untuk menciptakan lingkungan belajar jarak jauh yang penuh dengan pengalaman menarik melalui interaksi.

Model pembelajaran terbuka merupakan suatu model pembelajaran yang bertabiat terbuka dan bisa diiringi oleh siapapun tanpa terdapatnya batas umur belajar, tahun ijazah, waktu registrasi, ataupun frekuensi dalam menjajaki tes. Tiap mereka yang mempunyai peluang belajar tanpa hambatan apapun (Bates 1995), yang maksudnya siapapun boleh di daftarkan jadi mahasiswa, siapapun leluasa mengambil Mata kuliah cocok yang di butuhkan, serta leluasa menuntaskan kuliahnya kapanpun. Pembelajaran terbuka lebih berarti leluasa dari keterbatasan, Dewal (1986) Mengemukakan kalau model pembelajaran jarak jauh lebih mengacu pada terdapatnya modus ataupun sistem penyampaian proses belajar sehingga sistem pembelajaran yang terbuka lebih mengacu kepada pergantian struktur dari organisasi pembelajaran, serta jadi sesuatu organisasi terbuka terkait tempat, waktu, modul pendidikan, serta sistem melaporkan kalau sistem pembelajaran jarak jauh lebih mengacu kepada sistem (modus) penyampaian proses pendidikan, hingga sistem pembelajaran terbuka lebih mengacu kepada pergantian struktur organisasi pembelajaran, jadi sesuatu organisasi yang terbuka dalam perihal tempat, waktu, modul pendidikan, serta sistem pendidikan (Putri \& Ridha, 2020).

Adapun pada Pendidikan jarak jauh, sistem pembelajaran yang dilakukan pada dasarnya tidak secara tatap muka ataupun tidak dilaksanakan di dalam kelas titik proses pembelajaran ini biasanya dilakukan dengan menggunakan bantuan media sebagai penunjang titik misalnya seperti internet, siaran radio, aplikasi telepon, televisi, komputer, maupun berbagai bentuk media cetak atau modul. Yusufhadi Miarso (2005:304) mengatakan bahwa pada dasarnya pendidikan jarak jauh dan pendidikan terbuka adalah sama. Model pendidikan ini sama-sama berlangsung sepanjang hayat, serta berorientasi terhadap kepentingan, keadaan, serta karakteristik peserta didik dan beragam pola pembelajaran yang menggunakan beraneka sumber pembelajaran. Ada keterpisahan antara Pendidik dan peserta didik secara lintas ruang maupun waktu, sehingga proses belajar yang dilakukan dapat secara mandiri, akan tetapi tetap dalam pantauan pendidik atau dosen di dalam situasi pandemi covid 19 Saat ini Pemerintah juga menghimbau agar dilakukan kegiatan pembelajaran maupun bekerja dari rumah. Hal tersebut menjadikan pendidikan jarak jauh akhirnya menjadi pilihan utama dalam proses pembelajaran Pendidikan di instansi pendidikan manapun titik sistem pendidikan tersebut dipercaya bisa membantu pendidik maupun dosen agar dapat tetap berkomunikasi dengan 


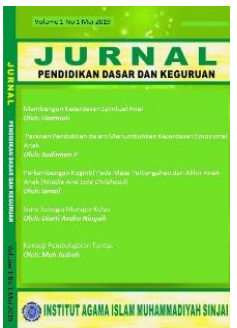

JURNAL

Pendidikan Dasar dan Keguruan

Volume 6, No. 1, 2021

ISSN (print) : 2527-578X

ISSN (Online): 2715-6818

Homepage : http://journal.iaimsinjai.ac.id/index.php/JPDK

peserta didiknya dapat tetap melakukan proses belajar-mengajar meskipun dari rumah masingmasing (Putri \& Ridha, 2020).

Berdasarkan kajian literatur dalam manuskrip ini, model pembelajaran yang sesuai dengan kondisi kenormalan baru saat ini, adalah model pembelajaran menurut Bates yaitu model pembelajaran terbuka. Model pembelajaran tersebut, dapat mengakomodasi kebutuhan pembelajaran peserta didik yang saat ini terbatas pada ruang, waktu, maupun sumber daya.

\subsection{Pendidikan di Masa Pandemi}

Problematika pendidikan di masa pandemi banyak mengganggu harmonisasi kehiduapan masyarakat, karena sendi-sendi normatif dan tradisional mengalami pergerseran yang belum menemukan penyelesaian yang baik dalam sebuah pelaksanaan pendidikan Islam. sebagian masyarakat selama pandemi merasakan adanya krisis kepercayaan akan kemampuan diri pribadi, sehingga timbul gejala transisi yang cukup sensitif terkait nilai-nilai yang lainnya (Nuriyati, 2020). Menurut Asmuni (2020), permasalahan tersebut terdiri dari adanya masalah dari sisi pendidikan berupa kurangnya penguasaan terkait IT, dan keterbatasan akses dalam pengawasan partisipan didik. Sebaliknya dari sisi partisipan didik, terbentuknya kekurangaktifan dalam menjajaki proses pendidikan, terdapatnya keterbatasan sarana pendukung ataupun keterbatasan jaringan internet. Terdapat pula keterbatasan dari sisi orang tua berbentuk minimnya waktu dalam proses pendampingan kanak- kanak dalam pendidikan daring di masa pandemi.

Sebuah artikel menuliskan perubahan paradigma pendidikan oleh disrupsi Covid-19 secara tidak langsung. Pandemi ini telah mengganggu sistem pendidikan dan mengakibatkan pendidikan kehilangan relevansinya (Salkiah, 2020). Peran teknologi saat ini telah berubah menjadi media dalam proses interaksi pendidik dan peserta didik pada proses pembelajaran daring (Hanifah Salsabila et al., 2020). Dahulunya sekolah yang berfokus pada keterampilan akademik tradisional, kini beralih menjadi model pembelajaran online yang lebih condong terhadap pemberian peluang kemampuan berpikir kritis serta kemampuan adaptasi peserta didik (Salkiah, 2020).

Teknologi Saat ini juga telah memiliki peran dalam memberikan fasilitas pendidikan bagi pendidik dalam penyampaian materi pembelajaran sehingga dapat tetap berlangsung meskipun tanpa dilakukan secara tatap muka. Pada proses penerapannya, ada bermacam hambatan serta tantangan tertentu untuk para pelakon pembelajaran Spesialnya yang berkaitan dengan budaya akademik semacam evaluasi hendak nilai, perilaku, pengetahuan keahlian, pula kesiapan fasilitas prasarana yang berhubungan dengan teknologi (Hanifah Salsabila et al., 2020). Adapun proses penyelenggaraan Literasi serta pelatihan yang berhubungan pemanfaatan teknologi, menjadi sebuah solusi baru dalam menghadapi tantangan pendidikan jarak jauh selama masa pandemi covid 19 kini (Hanifah Salsabila et al., 2020).

Permasalahan dari pembelajaran jarak jauh (online) pada masa pandemi diantaranya yaitu kurangnya akses terhadap jaringan telekomunikasi di daerah terpencil, Sedangkan di daerah perkotaan tidak diragukan lagi ketersediaannya di Indonesia utamanya di pulau yang jarang penduduknya, akses jaringan telekomunikasi masih kurang sehingga untuk melaksanakan pembelajaran jarak jauh (online) mengalami kesuliatan. Rendahnya keterampilan teknologi bagi masyarakat yang kurang mampu untuk belajar teknologi dan banyak pendidik yang terdahulu yang tidak ingin belajar mengikuti perkembangan zaman. Selain itu, biaya terkait koneksi internet secara umum masih banyak masyarakat Indonesia yang kurang dapat mememuhinya. Mereka yang rutin membeli hanyalah dari kalangan 


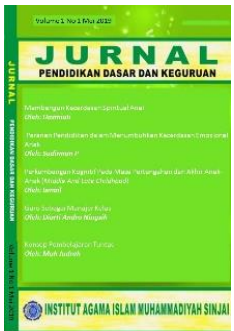

JURNAL

Pendidikan Dasar dan Keguruan

Volume 6, No. 1, 2021

ISSN (print) : 2527-578X

ISSN (Online): 2715-6818

Homepage : http://journal.iaimsinjai.ac.id/index.php/JPDK

menengah ke atas namun bagi mereka yang golongan menengah ke bawah kurang mampu untuk mengkonsumsinya (Nuriyati, 2020).

Literatur menunjukkan bahwa problematika pendidikan modern dimasa pandemi ini adalah perubahan paradigma pendidikan ke model pembelajaran jarak jauh atau sering disebut pembelajaran online atau e-Learning. Pembelajaran jarak jauh ini, menimbulkan berbagai problematika baik dari sisi pendidik, peserta didik, maupun dari sisi fasilitas pendukung pembelajaran. Dibutuhkan suatu perubahan atau inovasi untuk menyelesaikan permasalah pendidikan tersebut.

Membangun dan memperbaiki program pendidikan yang telah terjadi saat ini maka harapan kedepannya dapat membuat perencanaan program yang mengidentifikasikan masalah pokok yang menghambatnya. Berpikir kreatif dapat membuat inovasi baru dalam sebuah lembaga pendidikan. Sistem dan metode pendidikan yang tepat digunakan dalam proses kependidikan Islam yang kontektual dengan iptek yang mudah di dapatkan. Hal yang lebih penting adalah harapan agar peserta didik lebih mampu untuk mengendalikan serta menangkal dampak negatif Iptek terhadap nilai etika agama Islam, serta moral dan nilai yang harus lebih dimanfaatkan dalam kehidupan individual maupun bersosial (Nuriyati, 2020). Di era modern ini, pembelajaran e-learning merupakan bagian dari proses modernisasi. Dengan adanya modernisasi, ajaran Islam akan dapat disesuai dengan perkemangan zaman yang sangat dinamis (Nata, 2011). Dibutuhkan suatu perubahan atau inovasi untuk menyelesaikan permasalah pendidikan khususnya di era pandemi ini (Nuriyati, 2020; Yusuf et al., 2020). Perubahan dari segi model pembelajaran adalah suatu keharusan agar capaian tujuan pembelajaran dapat optimal.

\section{Kesimpulan}

Problematika pendidikan modern dimasa pandemi ini adalah perubahan paradigma pendidikan ke model pembelajaran jarak jauh atau sering disebut pembelajaran online atau $e$ Learning. Pembelajaran jarak jauh ini, menimbulkan berbagai problematika baik dari sisi pendidik, peserta didik, maupun dari sisi fasilitas pendukung pembelajaran. Dibutuhkan suatu perubahan atau inovasi untuk menyelesaikan permasalah pendidikan tersebut. Analisis yang sesuai dengan keadaan saat sekarang ini di mana dunia sedang dilanda wabah covid-19, yang tentunya juga sangat berpengaruh pada dunia pendidikan, dengan adanya desain model pembelajaran dari Anthony W. Bates ini sangat menunjang, melihat keadaan sekarang yang mengharuskan melakukan proses pembelajaran secara online atau jarak jauh. Tinggal bagaimana seorang pendidik memberikan metode atau cara terbaiknya dalam melakukan proses pembelajaran dan juga sesuai dengan model pembelajran $e$-learning yang merupakan respon dunia pendidikan dalam menyikapi perubahan tersebut.

\section{Daftar Pustaka}

Ansori, A., \& Sari, A. F. (2020). Inovasi Pendidikan di Masa Pandemi Covid-19. Jurnal Literasi Pendidikan Nusantara, 1(2), 133-148.

Asmuni, A. (2020). Problematika Pembelajaran Daring di Masa Pandemi Covid-19 dan Solusi Pemecahannya. Jurnal Paedagogy, 7(4), 281. https://doi.org/10.33394/jp.v7i4.2941

Farida, I., \& Yuliana, E. (2014). SIKAP MAHASISWA MEMANFAATKAN TEKNOLOGI INFORMASI DAN KOMUNIKASI DALAM PEMBELAJARAN TERBUKA DAN 


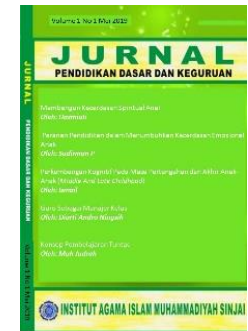

JURNAL

Pendidikan Dasar dan Keguruan

Volume 6, No. 1, 2021

ISSN (print) : 2527-578X

ISSN (Online): 2715-6818

Homepage : http://journal.iaimsinjai.ac.id/index.php/JPDK

JARAK JAUH. Jurnal Pendidikan Terbuka Dan Jarak Jauh, 15(2), 112-121. https://doi.org/10.33830/ptjj.v15i2.594.2014

Hanifah Salsabila, U., Irna Sari, L., Haibati Lathif, K., Puji Lestari, A., \& Ayuning, A. (2020). Peran Teknologi Dalam Pembelajaran Di Masa Pandemi Covid-19. Al-Mutharahah: Jurnal Penelitian Dan Kajian Sosial Keagamaan, 17(2), 188-198. https://doi.org/10.46781/al-mutharahah.v17i2.138

Hsu, L. Y., Chia, P. Y., \& Lim, J. F. (2020). The Novel Coronavirus (SARS-CoV-2) Epidemic. Annals of the Academy of Medicine, Singapore, 49(1), 1-3. https://doi.org/10.47102/annals-acadmedsg.202051

Nasruddin, R., \& Haq, I. (2020). Pembatasan Sosial Berskala Besar (PSBB) dan Masyarakat Berpenghasilan Rendah. SALAM: Jurnal Sosial Dan Budaya Syar-I, 7(7), 639-648. https://doi.org/10.15408/sjsbs.v7i7.15569

Nata, A. (2011). Studi Islam Komprehensif - Prof. DR. H. Abuddin Nata, MA. (Pertama). Kencana Prenada Media.

Nuriyati, T. (2020). Problematika Pendidikan Islam di Masa Pandemi. In A. Wijayanto, A. Asrifan, Yulianti, \& R. Festiawan (Eds.), Adaptasi Kebiasaan Baru Masyarakat Indonesia Pada Era Pandemi COVID-19: Tinjauan Berbagai Disiplin Ilmu (Issue December, pp. 44-50). Akademia Pustaka.

Pakpahan, R., \& Fitriani, Y. (2020). Analisa Pemafaatan Teknologi Informasi Dalam Pemeblajaran Jarak Jauh Di Tengah Pandemi Virus Corona Covid-19. JISAMAR (Journal of Information System, Applied, Management, Accounting and Researh), 4(2), 30-36.

Putri, W., \& Ridha, I. (Eds.). (2020). Kampus Merdeka Seri 5: Transformasi Media Pengajaran Kampus Merdeka di Era Kenormalan Baru (Seri ke li). Syiah Kuala University Press. https://books.google.co.id/books?hl=id\&lr=\&id=0wcUEAAAQBAJ\&oi=fnd\&pg=PA57 $\& d q=$ pembelajaran+terbuka\&ots=IVaSHRqfQ-

$\&$ sig=wSrmDbi7rdwrUtttfDUpEPYWiBs\&redir_esc=y\#v=onepage \&q=pembelajaran terbuka\& $\mathrm{f}=$ false

Salkiah, B. (2020). Perubahan Paradigma Pendidikan dan Ekonomi di Masa Pandemi Covid19. Media Bina Ilmiah, 15(1), 3781-3787.

Saragih, A. H., \& Septamia, N. U. (2019). Analisis Penerimaan Pengguna E-Filing Menggunakan Model Unified Theory Acceptance and Use of Technology (UTAUT). Jurnal Kajian Akuntansi, 3(1), 1. https://doi.org/10.33603/jka.v3i1.2129

Sudrajat, J. (2020). Kompetensi Guru di Masa Pandemi Covid-19. Jurnal Riset Ekonomi Dan Bisnis, 13(1), 106.

Sundari, F. S., \& Muliyawati, Y. (2017). ANALISIS KETERAMPILAN DASAR 
Pendidikan Dasar dan Keguruan

Volume 6, No. 1, 2021

ISSN (print) : 2527-578X

ISSN (Online): 2715-6818

Homepage : http://journal.iaimsinjai.ac.id/index.php/JPDK

MENGAJAR MAHASISWA PGSD. Pedagonal : Jurnal Ilmiah Pendidikan, 1(1), 26-36. https://doi.org/10.33751/pedagog.v1i1.225

WHO. (2020). Novel Coronavirus (2019-nCoV) SITUATION REPORT - 1. In https://www.who.int/docs/default-source/coronaviruse/situation-reports/20200121sitrep-1-2019-ncov.pdf (Vol. 10, Issue January). https://doi.org/10.13070/mm.en.10.2867

Yusuf, M., Hamdani, Siregar, A. P., \& Siregar, F. N. (2020). Implementasi Pendidikan Agama Islam di Masa Pandemi Covid-19. Maslahah Jurnal Pengabdian Masyarakat, 1(1), 3848. https://doi.org/10.30596/maslahah.v 